\title{
Rubber Agroforestry Experiments in Jambi at the end of a 25-Year Cycle
}

\author{
Akiefnawati Ratna $^{l}$, van Noordwijk Meine $^{2}$, and Tata Hesti Lestari ${ }^{3}$ \\ ${ }^{1}$ Independent researcher, Muara Bungo, Indonesia \\ ${ }^{2}$ World Agroforestry (ICRAF), Bogor, Indonesia \\ ${ }^{3}$ Forestry and Environment Research, Development, and Innovation Agency (FOERDIA), Bogor, \\ Indonesia
}

\begin{abstract}
The rubber agroforestry experiments in Jambi started with the theory of change that productive clonal rubber could be economically used in low-labour intensity rubber agroforests, allowing selective retention of forest species or planted fruit trees in interrows. At the end of what was expected to be a 25 -year production cycle we revisited the farmers (or their next generation), recorded what had happened to the plot and registered farmer plans for a way forward. Qualitatively, the results showed a wide range of directions of actual change. The envisaged plots, with full-grown tapped rubber in a secondary forest setting did occur - but as exception rather than rule. Some plots had early on been converted to oil palm when white root rot disease killed many of the rubber trees. Others were in a gradual transition to oil palm, already interplanted, or depended on natural regeneration of rubber within the plot for the trees currently being tapped. Some plots had been completely destroyed as the land was sold to a local coal-mine developer. Overall tapping frequency was low, as farmgate rubber prices have in recent years been low and farmers had other options (including participating in small-scale gold mining). Farmer experience with the various clones tested led to mixed opinions on which (if any) of the clones introduced were superior to what farmers used in the past (and what still regenerates in the landscape). GT1, a robust clone, was seen as hardly more productive as local germplasm, the PB260 and BPM1 clone were productive, but especially $\mathrm{PB} 260$ clone sensitive to white root rot disease. The quality of rubber wood was a concern for some farmers. The most successful intervention, from farmers' as well as environmental perspective, has probably been the interplanting of meranti (Shorea leprosula) or tembesu (Fagraea fragrans) trees in young rubber stands, with good prospects for generating substantial income.
\end{abstract} Keywords: RAS (Rubber Agroforestry System), Indonesia, interplanting 


\section{Introduction}

Para rubber (Hevea brasiliensis) was introduced into Jambi in equatorial Sumatra in 1904, with seed supply supported by downstream traders who had a captive market as all transport of goods and people at that time was based on the Batanghari river and Jambi city controlled trade at the outflow (Martini et al. 2010). Jambi province has a coastal zone with peatlands that became the last frontier of settlements in the 1990's, a lowland peneplain of acid upland soils of moderate fertility after the forest was gone, a foothill zone to the Bukit Barisan range with better soils, and the mountain range (van Noordwijk et al. 1998). Rubber was planted in the lowland peneplain and foothills between food crops such as rice and vegetables and was allowed to grow into a fallow vegetation with spontaneously established forest trees, until the trees could be tapped and part of the vegetation was cleared for ease of access. The so called 'jungle rubber' system (Gouyon et al. 1993) proved to be a low-cost production system, adapted to local circumstances and to a flexible labour pool. If rubber process were good external labour was absorbed to tap, if prices were low people might shift, for example to highland coffee or cinnamon in Kerinci (Tomich et al. 1998). A trajectory of change started in the 1970's when the Trans Sumatra highway and transmigration programs increased access and population density ((van Noordwijk et al. 2012). Initially the logging industry opened up tracts of land, but by the 1990's the forest frontier was closing, and intensification on existing farmland and secondary forests became the main opportunity (Murdiyarso et al. 2002). Experiments on intensifying rubber agroforestry started in Jambi on 1995, with the 'theory of change' that productive clonal rubber could be economically used in low-labour intensity rubber agroforests, allowing selective retention of forest species or planted fruit trees in interrows (Penot, 2004; Joshi et al. 2002). At the end of what was expected to be a 25 -year production cycle we revisited the farmers (or their next generation), recorded what had happened to the plot and registered farmer plans for a way forward.

\section{Methods}

\subsection{On farm experiments}

Clonal rubber planting supported by the SRAS (Smallholder Rubber Agroforestry System) project of CIRAD/GAPKINDO/ICRAF and the Indonesian ASB (Alternative Slash and Burn) partnership for the tropical forest margins started in December 1995, in collaboration with rubber farmers in the villages Muara Buat, Rantau Pandan, and Sepunggur in Bungo District; and Aur Duri and Pulau Temiang in Tebo District in Jambi Province. The treatments included:

1. RAS (Rubber Agroforestry System) type 1 where standard 'jungle rubber' practices of farmers in Jambiwere retained, but instead of local rubber seedlings, clonal (grafted) rubber was used (GT1, PB260, RRIC 100, RRIM 600, BPM 1, IRR 42 or IRR 118); weeding was limited to the rubber tree rows, allowing the natural regeneration of forest species in the interrows, with subsequent selective retention by farmers of trees considered to be of value. The RAS1 system has a low labour requirement and was considered to be easy to implement by farmers. In some experiments the use of $\mathrm{N}$ and $\mathrm{P}$ fertilizer to promote initial growth of the rubber trees was tested.

2. In RAS type 2 experiments, first year planted upland rice (or other annual crops) was used in the interrows, followed by the established of selected fruit or timber trees. 
Most of the experiments were researcher-designed, farmer-implemented on-farm experiments, with additional experiments where farmers had a larger say in the design (Williams et al. 2001) demonstrating the range of technical and non-technical issues that interact with clonal rubber establishment in the reality of local livelihoods. In practice, however, the implementation of RAS experiments, and especially the amount of labour invested in weeding proved to be highly variable and correlated with initial rubber growth rates (Wibawa et al. 2006).

Subsequent experiments also tested slash-and-mulch methods of initial land clearing (Ketterings et al. 1999), a 'gap regeneration' technology based on the 'sisipan' method (Joshi et al. 2003, 2005), and enrichment planting in existing stands with Meranti (Shorea leprosula) planted interrow of rubber (Tata et al. 2012, 2014).

\subsection{Site conditions}

Sepunggur Village (Bathin II Babeko sub-district, Bungo District) in the lowland peneplain at $37 \mathrm{~m}$ above sea level has a population of 3,176 persons ( $51 \%$ female) on $99 \mathrm{~km}^{2}$ and a population density of $31 \mathrm{~km}^{-2}$. The area of Sepunggur Village is $99 \mathrm{~km}^{2}$ (BPS Bungo, $2020)$. Rubber gardens ( $45 \%$ of the area) and smallholder oil palm ( $8 \%$ of the area) are the main sources of livelihoods.

The Rantau Pandan Village, in the foothills at $97 \mathrm{~m}$ above sea level has a population of 3,503 persons ( $49 \%$ female) on $71 \mathrm{~km}^{2}$ and a population density of $50 \mathrm{~km}^{-2}$ (BPS Bungo, 2020). It has the largest coal reserves in Bungo District. The agroforests of the village are famous for producing fruits such as rambutan, durian, rambei, cempedak and others.

\subsection{Revisiting farmers in 2021}

In February 2021, 25 years after the first SRAS experiments were planted, we revisited (within the constraints to fieldwork by the COVID19 pandemic) 'SRAS' farmers in Bungo and Tebo Districts. The observation methods used were based on a direct visit to the SRAS sites to observe tapping activities and the current condition of plantation land cover. We met the owner/farmer and brought up a number of points in a free-flowing conversation: These visits updated the contact information of farmers who still want to share further data. Results are presented here in anonymised form.

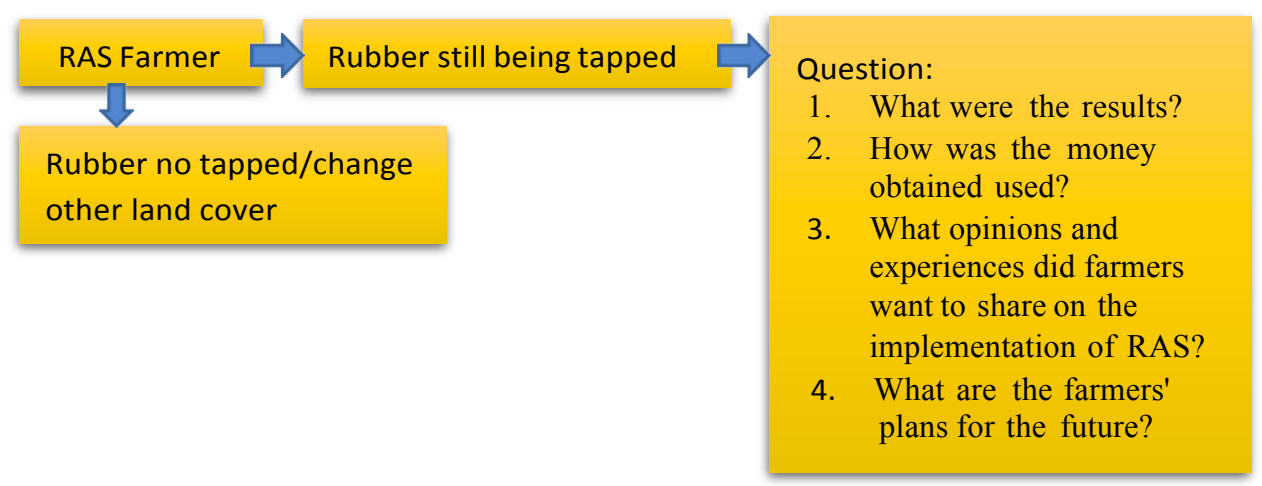

Fig. 1. Interview flow. 


\section{Results}

In only 11 farmers from 27 farmers visited in 2021 that of the RAS experimental plots had clonal rubber stems that were currently tapped. In some plots a next generation of rubber trees, spontaneously established from seed, was currently being tapped. Some had la rge rubber trees available for tapping if prices and labour conditions would make that relevant. Other plots had been converted to oil palm, were in the process of conversion, or had been sold to a local coal mining entreprise. Some plots had a healthy growth of timber trees. We will discuss observation based on this post-hoc classification.

\subsection{Plots where rubber trees continue to grow and are still being tapped}

Farmers are still tapping the rubber stems that are still alive (Fig. 2) and are growing saplings of clonal rubber. These farmers depend on rubber latex for family income, medical expenses and for school fees for their children; some had used the proceeds from selling rubber latex to pay for a pilgrimage to Mecca (Saudi Arabia).
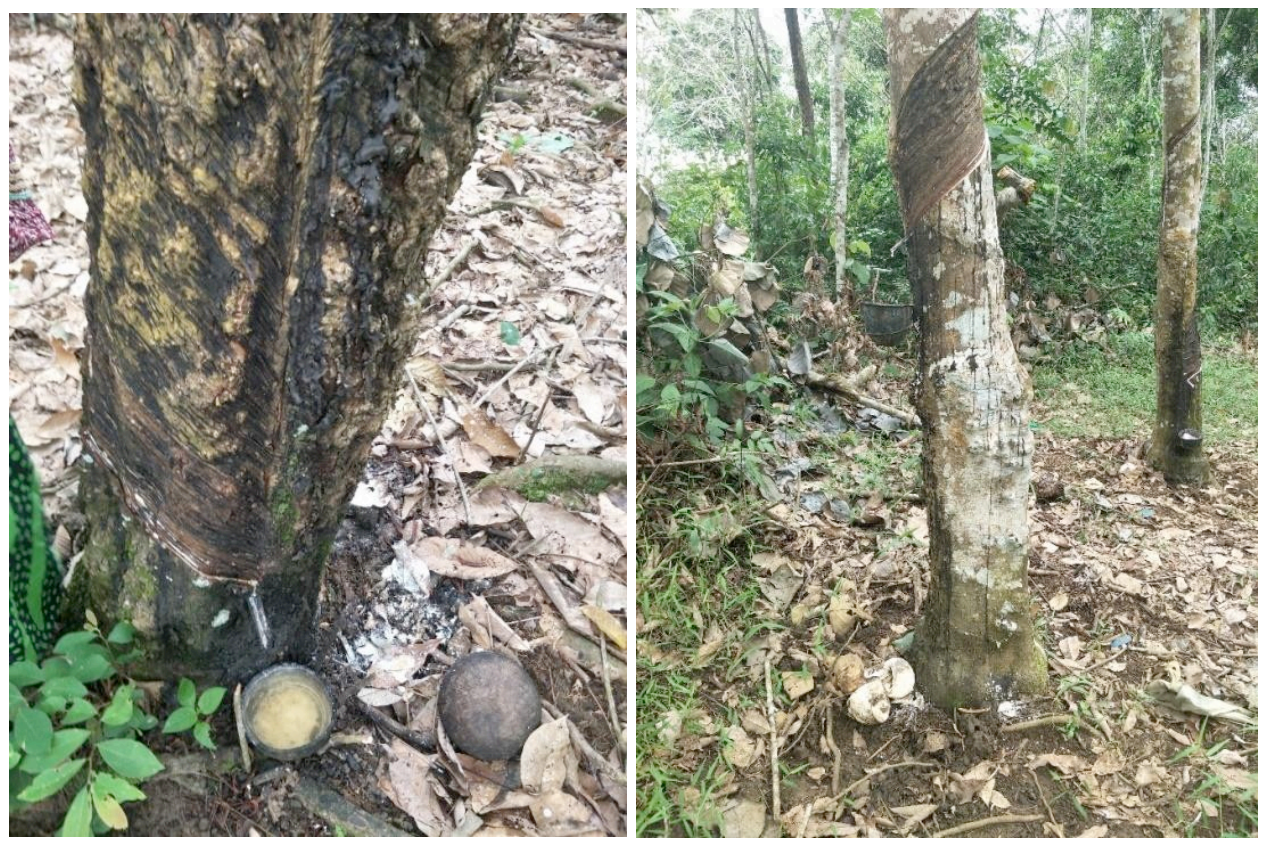

Fig. 2. Rubber (PB260 clone) in Sepunggur Village still being tapped.

\subsection{Rubber trees continue to grow and are not tapped}

Rubber trees of the PB260 and IRR clones had died from attack by the white root fungus disease in several of the plots. According to farmers, the BPM1 clone had been the most resistant to fungalattack. Tapping results for PB260, RRIC100, RRIM600 and BPM1 clones had been better than expected for local rubber germplasm, while GT1 results were considered to be average. Although not currently being tapped, farmers still let the clonal rubber trees grow, as there were valuable meranti (Shorea leprosula) (Fig. 3), tembesu (Fagraea fragrans) (Fig. 4) and various local fruit trees in the plot. As other sources of 
wood had become scarce, e.g. for house building or repair, they expected to use the wood locally.

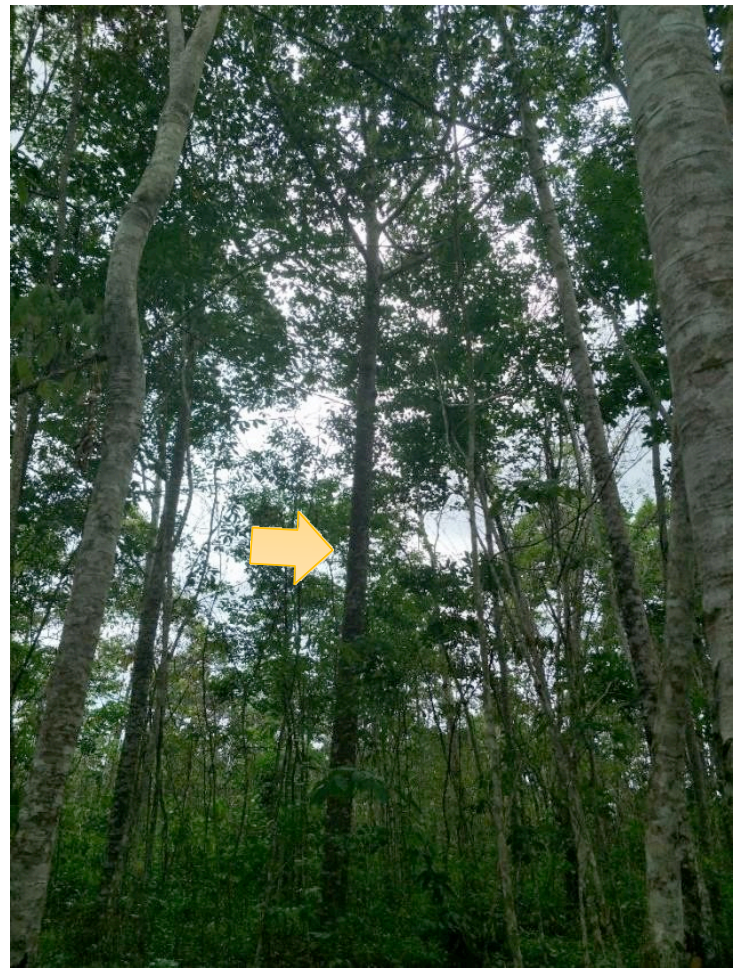

Fig. 3. The growth of meranti trees in a clonal rubber plantation with an agroforestry pattern in Sepunggur Village - Bungo District. 


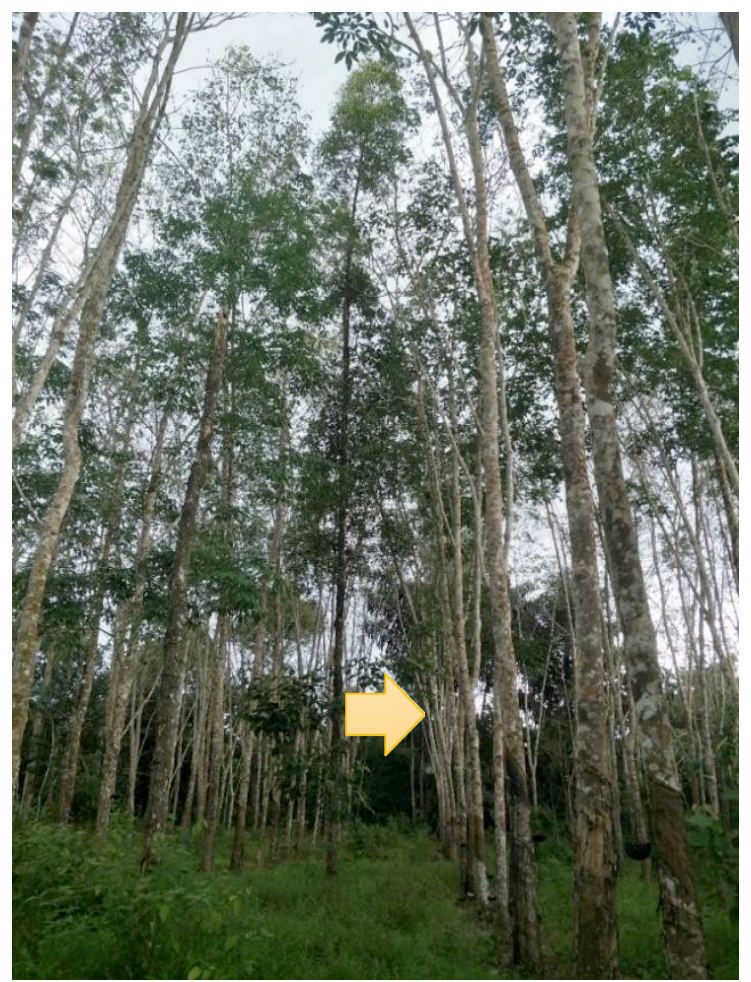

Fig. 4. The growth of Tembesu trees in a clonal rubber plantation with an agroforestry pattern in Aur Duri Village - Tebo District.

\subsection{Rubber trees have been felled and land use switched to oil palm and Coal Mining}

Most of the rubber agroforestry where trees had died due to white root fungus disease have been converted to changed to oil palm (Fig. 5), or where in the process of conversion by interplanting methods (Fig. 6). One of the plots had been converted to a coal mine and still had no land cover (Fig. 7). Farmers expected the oil palm to be resistant to white root rot and other diseases. Farmers followed the practices of neighbours who planted oil palm before and had worked in commercial oil palm plantations. They expect oil palm to require less labour than rubber farming. 


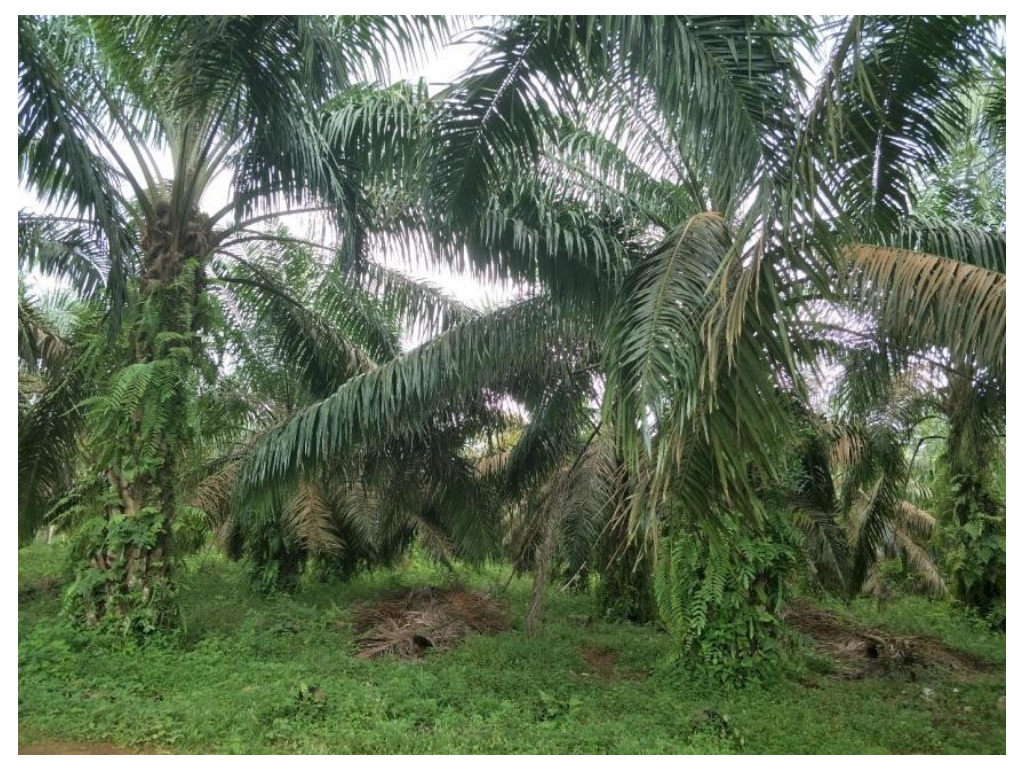

Fig. 5. Oil palms were planted 10 years ago. After many rubber trees died, so the yield of rubber production was low, the farmers decided to cut them down and change to planting oil palm.

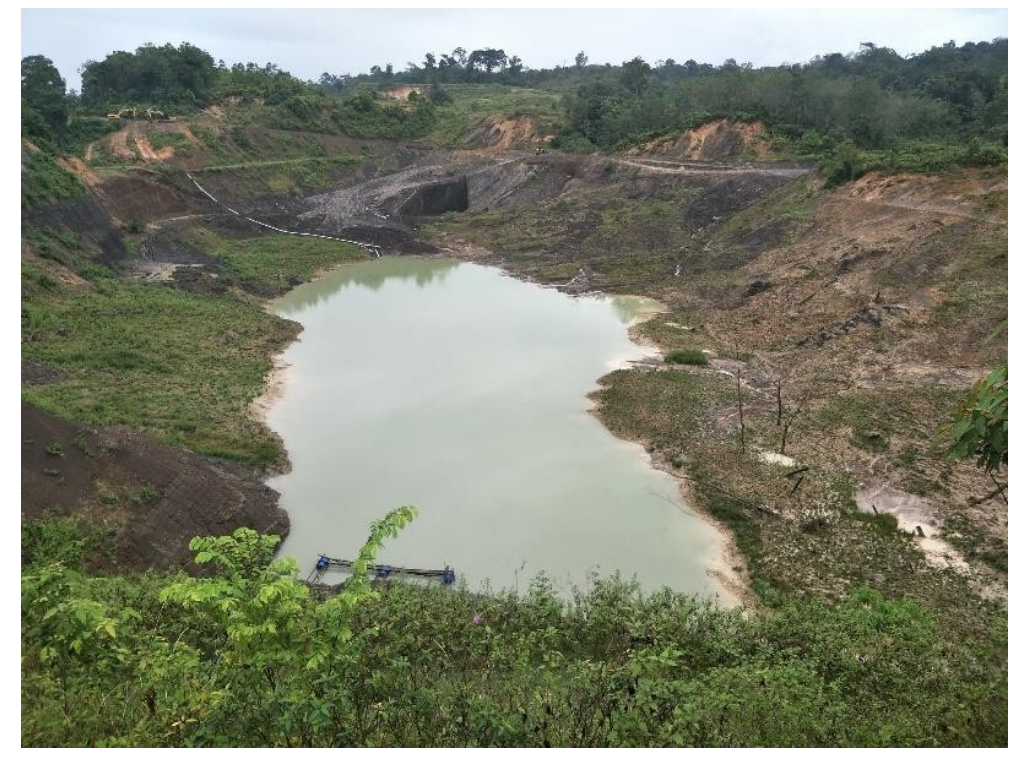

Fig. 6. Oil palm saplings interplanted to replace old rubber trees. 


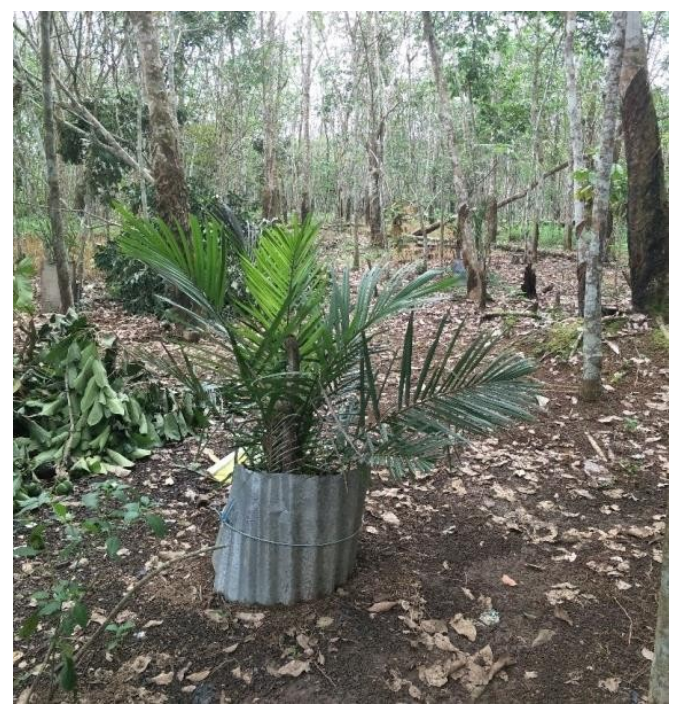

Fig. 7. Former coal mine that replaced one to the Rubber Agroforest Systems plots in Rantau Pandan Village.

\subsection{Farmer experience with intensified rubber agroforestry systems}

After the direct project engagement by ICRAF and partners stopped in the area, farmers mostly returned to the local rubber pattern, such as:

- Few farmers applied fertilizer after the trial status (with free fertilizer supply) ended in the SRAS project in 2008.

○ Many clonal rubber trees have died from the attack of white root fungus disease, even though they have been treated with the same recommendations and methods as ICRAF. Finally, the farmers decided to cut them down and replace them with oil palm plants, sold the land to coal mining entrepreneurs or sold land to their children or other people who planted oil palm.

- Even though the price of rubber latex has fallen to Rp. $5,000 \mathrm{~kg}^{-1}$, some farmers are still tapping rubber to meet household needs.

- Farmers have not tapped the rubber stems upwards; they are waiting for a minimum farmgate price of around Rp. $10,000 \mathrm{~kg}^{-1}$ of rubber slab to tap and get enough money for rejuvenating their rubber. The technique for upward tapping (local term 'injected') will result in the death of the rubber stem.

- The proliferation of oil palm cultivation in the area has influenced the thinking of farmers to plant that crop, even though they did not understand how to plant it and how to maintain it.

- The PB260 clone was liked by farmers because it had a lot of latex, but has low resistance to white root fungus. The BPM1 clone had better resistance to white root fungus attack, so that up to 25 years of age the trees can still be tapped. Meanwhile, the GT1 clone was not favoured by farmers because the latex yields don't differ much from local rubber. Meanwhile, the quality of the wood of IRR clones was not particularly good, so the selling price was low. 


\section{Discussion}

At the end of what was expected to be a 25-year production cycle the results showed a wide range of directions of actual change. The envisaged plot conditions, with full-grown tapped rubber in a secondary forest setting did occur - but as exception rather than rule. The importance of white root rot disease that killed many of the clonal rubber trees had not been foreseen in the project design, but the use of multiple clones had provided opportunities to get experience with the differential resistance among the clones. Some farmers depended on natural regeneration of rubber within the plot for the trees currently being tapped. We did not see any evidence of farmers buying clonal rubber for establishment of new rubber agroforestry plots; rather they relied on the seedlings they found under trees with good performance, as they had done before. How much of the latex production capacity is transferred to the next tree generation is not clear.

The role played by local trees as part of rubber agroforests (Tata et al. 2008, 2009) could not be replicated in the RAS experiments, as the surrounding landscape mosaic changed character and the free influx of forest tree seeds has probably been diminished. Where local trees, including meranti and tembesu, were planted from nursery stock good results were obtained, however, suggesting the landscape has reached a next stage in the tree diversity transition curve (Ordonez et al. 2014).

The success with meranti planting, where experiments showed only a limited response to and need for inoculation with mycorrhiza (Tata et al. 2010), had not brought farmers to establish nurseries to replicate this success. The dependence on what grows naturally, or comes to the farm from well-intended outsiders, is a pattern not easily abandoned, even if economic rationality would suggest otherwise. Before the current visits we had learned in the Lubuk Beringin Village that had become Indonesia's first 'Village Forest' based on rubber agroforestry (Akiefnawati et al. 2010), that the meranti interplanting in their rubber agroforestry had been a success.

When met the farmers expressed their gratitude for learning about clonal rubber based the RAS pattern. They got benefits though the high rubber latex production as well as from meranti and tembesu wood for future needs and fruit trees for family consumption. Overall, the current tapping frequency was low because farmgate rubber prices have in recent years been low and farmers had other options (including participating in small-scale gold mining).

The ban of using fire for land clearing has meant to end of upland rice production (Ketterings et al. 1999), e.g. as part of the RAS2 system, while only part of the available paddy rice lands are used (Villamor et al. 2013). However, the economic conditions for 'outsourcing' staple food production and reliance on markets are still met (van Noordwij k et al. 2014)

The experience in the specific rubber plots matched the overall pattern for the landscape with a shift from forest to jungle rubber as primary target for expansion of oil palm (Villamor et al. 2014a). Earlier indications that local decision-making that resisted large-scale oil palm expansion, did not object to an increase of smallholder oil palm (Villamor et al, 2014b). 


\section{Conclusion}

The results have shown that at least some types of clonal rubber planting material can adapt well to the RAS (Rubber Agroforestry System) pattern of reduced labour investment compared to standard monocultural plantations. However, the initial theory of change that such blending of high-yielding rubber and forest-like growing conditions could form an alternative to oil palm expansion in the area had to be adjusted based on the diverging experience of the on-farm trial plots and the farm families managing them. Twenty-five years after the first RAS experiments started, clonal rubber tree had to be rejuvenated. Although RAS rubber farmers were very satisfied with the results of the rubber clones, they will not, for a variety of reasons, be able to replicate the RAS systems as envisaged. The introduction of high-quality timber provided arguments to maintain rubber agroforestry plots, and not convert them (yet) to oil palm. The combination of researcher-designed and farmer-managed experiments proved to be a fertile opportunity for increased understanding of the local social-ecological systems, but also highlighted the low degree of predictability of specific events, while supporting ideas that diversity can provide risk buffering.

\section{References}

1. Akiefnawati R, Villamor GB, Ayat A, Galudra G, van Noordwijk M. Stewardship agreement to reduce emissions from deforestation and degradation (REDD): Case study from Lubuk Beringin's Hutan Desa, Jambi Province, Sumatra, Indonesia . In InternationalForestry Review, 12(4), pp.349-360.(2010)

2. Gouyon A, De Foresta H, Levang, P. Does 'jungle rubber' deserve its name? An analysis of rubber agroforestry systems in southeast Sumatra. Agroforestry systems, 22(3), 181-206. (1993)

3. Joshi L, Wibawa G, Vincent G, Boutin D, Akiefnawati R, Manurung G, van Noordwijk M, Williams SE. Jungle rubber: a traditional agroforestry system under pressure. International Centre for Research in Agroforestry, ICRAF-SE Asia Bogor (Indonesia). ISBN 979-3198-04-4.(2002)

4. Joshi L, Wibawa G, Beukema HJ, Williams SE, van Noordwijk M. Technological change and biodiversity in the rubber agroecosystem. pp 133-157, in: Vandermeer J (Eds.) Tropical Agroecosystems: New Directions for Research. CRC Press, Boca Raton, Florida, USA (2003)

5. Joshi L, van Noordwijk M, Sinclair FL. 2005. Bringing local knowledge in perspective: A case of sustainable technology development in jungle rubber agroforests in Jambi, Indonesia. pp 277-289, in: Neef A (Eds.) Participatory Approaches for Sustainable Land Use in Southeast Asia. White Lotus Press, Bangkok (Thailand).

6. Ketterings QM, Wibowo TT, van Noordwijk M, Penot E. Farmers' perspectives on slash-and-burn as a land clearing method for small-scale rubber producers in Sepunggur, Jambi Province, Sumatra, Indonesia . Forest Ecology and Management 120: 157-169.(1999)

7. Martini E, Akiefnawati R, Joshi L, Dewi S, Ekadinata A, Feintrenie L, van Noordwijk M. Rubber agroforests and governance at the interface between conservation and livelihoods in Bungo district, Jambi province, Indonesia. Working Paper 124. World Agroforestry Centre (ICRAF), Bogor (Indonesia). , Indonesia. Indonesia (2010)

8. Murdiyarso, D., Van Noordwijk, M., Wasrin, U.R., Tomich, T.P. and Gillison, A.N., Environmental benefits and sustainable land-use options in the Jambi transect, Sumatra. Journal of Vegetation Science, 13(3), pp.429-438 (2002) 
9. Ordonez JC, Luedeling E, Kindt R, Tata HL, Harja D, Jamnadass R, van Noordwijk M. Constraints and opportunities for tree diversity management along the forest transition curve to achieve multifunctional agriculture. Current Opinion in Environmental Sustainability 6, 54-60 (2014)

10. Penot, E. From shifting agriculture to sustainable rubber agroforestry systems (jungle rubber) in Indonesia: a history of innovations processes. In: D. Babin (Ed.) Beyond tropical deforestation, UNESCO/Cirad, p 221- 250. ffhal-00173302f (2004)

11. Tata HL, van Noordwijk M, Werger MJA. Trees and regeneration in rubber agroforests and other forest-derived vegetation in Jambi (Sumatra, Indonesia). Journal of Forestry Research 5: 1-20. (2008a), http://forda-mof.org/files/120\%20Hesti\%20L, \%20et \%20all.pdf.

12. Tata HL, van Noordwijk M, Rasnovi S, Joshi L. Pengayaan jenis di wanatani karet. pp 222-238, in: Adnan H, H, Tadjudin D, Yuliani EL, Komarudin H, Lopulalan D, Siagian YL YL, Munggoro DW (Eds.) Belajar dari Bungo: Mengelola Sumberdaya Alam di Era Desentralisasi. Center for International Forestry Research (CIFOR)., Bogor (Indonesia), (2008b)

13. Tata HL, van Noordwijk M, Rasnovi S, Werger MJA. Forests as provider of tree diversity in rubber agroforest in lowland Sumatra. In: XIII World Forestry Congress ,Buenos Aires, Argentina, 18 - 23 October (2009), http://www.cfm2009.org/es/programapost/resumenes/uploads/Forests as providers F D.pdf.

14. Tata HL, van Noordwijk M, Summerbell A, Werger MJA. Limited response to nurserystage mycorrhiza inoculation of Shorea seedlings planted in rubber agroforestin Jambi, Indonesia. New Forests 39: 51-74, (2010), http://www.springerlink.com/content/5617565791281076/fulltext.pdf .

15. Tata HL, van Noordwijk M. 2012. Farmers participation on dipterocarp tree planting in smallholder rubber plantation. pp 38-41, in: Bozzano, M, Jalonen, R, Boshier D, Thomas E, Cavers S, Gallo L, Bordacs S, Smith P, Loo J (Eds.) The state of the World's Forest Genetic Resources, Thematic Study. FAO, Rome (Italy).

16. Tata HL, Akiefnawati R, van Noordwijk M. Enrichment planting using native species (Dipterocarpaceae) with local farmers in rubber smallholdings in Sumatra, Indonesia. pp 178-184, in: Bozzano, M, Jalonen, R, Boshier D, Thomas E, Cavers S, Gallo L, Bordacs S, Smith P, Loo J (Eds.) The state of the World's Forest Genetic Resources, Thematic Study. FAO, Rome (Italy), (2014)

17. Tomich TP, van Noordwijk M, Vosti SA, Witcover J. Agricultural development with rainforest conservation: methods for seeking best bet alternatives to slash-and-burn, with applications to Brazil and Indonesia. Agricultural Economics, 19(1-2), pp.159174, (1998)

18. van Noordwijk, M., Murdiyarso, D., Hairiah, K., Wasrin, U.R., Rachman, A. and Tomich, T.P., 1998. Forest soils under alternatives to slash-and-burn agriculture in Sumatra, Indonesia. In Soils of tropical forest ecosystems (pp. 175-185). Springer, Berlin, Heidelberg.

19. van Noordwijk M, Tata HL, Xu J, Dewi S, Minang PA. Segregate or integrate for multifunctionality and sustained change through landscape agroforestry involving rubber in Indonesia and China. pp 69-104, in: Nair PKR, Garrity DP (Eds.)

Agroforestry: The Future of Global Landuse. Springer, Dordrecht (the Netherlands), (2012)

20. van Noordwijk M, Bizard V, Wangkapattanawong P, Tata HL, Villamor GB, Leimona B. Tree cover transitions and food security in Southeast Asia. Global Food Security 3, 200-208 (2014) 
21. Villamor GB, Desrianti F, Akiefnawati R, Amaruzaman S, van Noordwijk M. 2013. Gender influences decisions to change land use practices in the tropical forest margins of Jambi, Indonesia. Mitig Adapt Strateg Glob Change 19(6), 733-756 (2013)

22. Villamor, G.B., Pontius, R.G. and van Noordwijk, M., Agroforest's growing role in reducing carbon losses from Jambi (Sumatra), Indonesia . Regional Environmental Change, 14(2), pp.825-834 (2014a)

23. Villamor, G.B., Le, Q.B., Djanibekov, U., van Noordwijk, M. and Vlek, P.L., Biodiversity in rubber agroforests, carbon emissions, and rural livelihoods: An agentbased model of land-use dynamics in lowland Sumatra. Environmental Modelling \& Software, 61, pp.151-165 (2014b)

24. Wibawa, G., Joshi, L., Van Noordwijk, M. and Penot, E.A., Rubber based Agroforestry Systems (RAS) as Alternatives for Rubber Monoculture System. In: IRRDB annual conference, 2006, Ho-chi-minh city, Vietnam. ffhalshs-00137596 (2006)

25. Williams SE, van Noordwijk M, Penot E, Healey JR, Sinclair FL, Wibawa G, Nilsson SI. On-farm evaluation of the establishment of clonal rubber in multistrata agroforests in Jambi, Indonesia. Agroforestry Systems 53: 227-237 (2001) 